\title{
$\alpha$

\section{Perspectives of Social Entrepreneurship in Portugal: Comparison and Contrast with International Theoretical Approaches}

Cristina PARENTE

Mónica SANTOS

Vanessa MARCOS

Daniel COSTA

Institute of Sociology - Faculty of Arts, University of Porto

Luísa VELOSO•

Centre for Research and Studies in Sociology - University Institute of Lisbon

\begin{abstract}
The aim of this article is to present and discuss the perspectives of social entrepreneurship conveyed by third sector organizations in Portugal in the context of the main international theoretical approaches. As part of a research project on social entrepreneurship in Portugal, the article analyses the content of 20 semi-structured interviews with key actors within the Portuguese third sector. It is assumed that the roles these actors play are a clear indicator of the importance their views can hold in defining the social entrepreneurship field in Portugal. This analysis enables us to conclude that heterogeneous views and blurred defined boundaries frame the debate on social entrepreneurship's processes and definitions, with some actors even rejecting it in favour of other concepts such as "social economy" or "solidarity economy". Nevertheless, the central issues that arose are associated with the individual qualities of the entrepreneur, as well as the sustainability of the initiatives.
\end{abstract}

Keywords: Social entrepreneurship, third sector, social economy, solidarity economy, key actors'perspectives.

\section{Introduction}

Social entrepreneurship is a relatively new term, both as an academic concept and as a political practice of institutions from different sectors of society. While

•e-mail: luisa.veloso@iscte.pt. This article forms part of the research project 'Social entrepreneurship in Portugal: The policies, the organizations and the practices of education/training', which is being led by the Institute of Sociology - Faculty of Arts of the University of Porto in partnership with the Association for Social Entrepreneurship and Sustainability of the Third Sector (A3S) and the Center for Research and Studies in Sociology of the University Institute of Lisbon. The project is being funded by the Portuguese Foundation for Science and Technology. 
some authors note that examples of social entrepreneurship can be found throughout contemporary history (Leadbeater, 1996; Nicholls, 2006), the emergence and visibility of this issue dates back to the 1990 s with the aim of describing the set of responses from civil society (in many different organizational shapes and forms) in order to tackle new forms of poverty and social exclusion. In Europe, the processes of social entrepreneurship emerged largely as a result of the Welfare State's progressive retreat from the provision of social services and as a consequence of the markets inability or unwillingness to meet these needs at fair and affordable prices. The goal was to grant third sector organizations economic freedom to strive for self-sustainability that would, through the professionalization of their management structures, encourage them to become more self-reliant.

Despite it being possible to frame the roots of social entrepreneurship in Portugal in the second half of the last century with the emergence of the cooperative movement promoted by such important figures as António Sérgio, it remains an unexplored and diffuse field of theoretical and empirical analysis. However, its presence is widespread within the discourses of politicians and the media. From the theoretical point of view, it is thought the processes of social entrepreneurship have their place within the third sector and that they are determined by a global context that is more or less favourable to their practice. In this context of societal adhesion to social entrepreneurial practices the third sector representatives, as well as those of related educational, research and development institutions retain a crucial position, on account of the role they may or may not play in its diffusion and implementation. It is therefore important to understand how these key actors, assuming their actions have an impact on the shape of social entrepreneurship in Portugal, view the field of social entrepreneurship. Consequently, we propose to contrast the main ideas contained in the international literature with the perspectives of the key actors interviewed in Portugal. This holds interpretative significance as it allows Portugal to be placed in the international panorama of recent debates on social entrepreneurship. Taking into account the specificities of the Portuguese society, a southern European country, with a duality and fragmentation of social benefits and the weight of Catholicism and clientelism (Santos, 1993; Ferreira, 1996; Franco et al, 2005), it is of crucial importance to discuss how these concepts emerge and are appropriated by third sector key actors, both at national and international levels. Attending to the diversity of this sector, we will distinguish types of entities that prefer the North American concept of social entrepreneurship or others concepts with more tradition in Europe, such as social economy or solidarity economy. Furthermore, the concept of "entrepreneurship" seems to be gaining momentum in the public and official discourse in Portugal. This can also lead us to a broader discussion about the impact of these approaches in a context where the third sector is highly dependent on the state and the latter is progressively shrinking its social interventions.

The appropriateness of contrasting 
Portugal with the international panorama is greater due to the fragile nature of the Welfare State in Portugal compared to the evident vigor of its Welfare Society (Santos, 1993), as well as its potential to reconfigure itself through social entrepreneurship processes.

The article begins by examining the current international theoretical framework as it seeks to provide an outline of the main approaches that shape the issue of social entrepreneurship. It goes on to describe some of the particularities of the institutional context of the Portuguese third sector, paying particular attention to the umbrella organizations being analyzed. Following the section on methodology, the article will discuss the results of the analysis of both the interviewees' perspectives of social entrepreneurship and of the other concepts that they include in this issue.

\section{Social entrepreneurship: Different perspectives on a concept under construction}

The concept of social entrepreneurship has sought to consolidate itself through a fusion of the principles of governance of non-profit organizations and the business tools and ideas from the management and business economics spheres. The inclusion of the methods of market mechanisms has been used essentially to overcome the welfare logic of traditional institutions - from the north-American non-profit sector heavily reliant on philanthropy to the religious and subsidiary institutions in Europe - thus seeking to find innovative and sustainable alternatives to social economic challenges, both old and new.

While the concept of social entrepreneurship is currently still far from maturity with its theoretical fragmentation and disparity often noted, the direction of this approach has been settled, sometimes by opposition, through pre-established North American and European academic traditions (Defourny \& Nyssens, 2010a) and in Latin America with the Latin American and SemiPeripheral School of Solidarity Economics (Razeto, 1993; 1997 cited in Gaiger and Correa, 2011).

It is possible in the North American school of thought to identify the influence of two theoretical approaches: the first stems from the evolution of the non-profit sector over the last three decades or so (Salamon, 1992; Emerson and Twersky, 1996), the second closer to the classic matrix or entrepreneurship and the role of the social entrepreneur (Alvord, Brown and Letts, 2003; Bornstein, 2007; Dees, 2001). The former has been developed as a result of the difficulties within the American philanthropy and charity model (Boschee and McClurg, 2003), which is a consequence of the economic contraction of the 1970s and 1980 s, that led the non-profit sector to resort to commercial activities as a means of ensuring their survival and ability to achieve their social objectives (Defourny and Nyssens, 2010a; Boschee and McClurg, 2003; Emerson and Twersky, 2006; Dart, 2004; Weerawardena and Mort, 2006). This approach, called 'earned income school of thought' (Defourny and Nyssens, 2010a) focuses on an analysis of the 'social purpose enterprise', 
the 'social purpose business' and 'community wealth enterprises'. These are business-style non-profit organizations that incorporate strongly market-oriented business procedures and planning and management tools to ensure the efficient use of resources and the achievement of their goal. In this light, social entrepreneurship is understood to be a set of commercial activities and strategies designed to obtain and create resources that can be used in furtherance of a social mission.

On the other hand, within the social innovation school of thought neither the organization nor the enterprise is the preferred unit of analysis; it is the role and the individual qualities of the social entrepreneur (Bornstein, 2007). Inherent to this perspective is the classification of social entrepreneurs as social innovators or agents of change, which by recourse to new and sustainable systems (Nicholls and Cho, 2006) engender profound changes within the systems in which they intervene. According to the Shumpetarian logic of the entrepreneur, social entrepreneurs offer new and better quality services as a result of the innovative combination of methods and factors of production, of new organizational forms and by their focus on new markets (Dart, 2004; Dees and Anderson, 2006; Defourny and Nyssens, 2010a). Underlying the idea of the social entrepreneur as a promoter of change is that of social innovation the means to achieve social impact and systemic transformation through the dissemination and replication of results (Alvord, Brown and Letts, 2003; Martin and Obsberg, 2007). This approach confers a great deal of freedom with respect to the type of resource and method used and the organizational formats adopted for the attainment of economic sustainability (Anderson and Dees, 2006; Peredo and MacLean, 2006; Dees, 2001; Defourny and Nyssens, 2010a).

With these two theoretical approaches, the North American school presents two broad themes: social entrepreneurs and their intrinsic personal qualities; and the use of business solutions as a tool to ensure the sustainability and economic efficiency of the organizations (Dees and Anderson, 2006).

The European school is strongly rooted in the social economy tradition that re-emerged at the end of the 20th century with the reforms of the Welfare State and its inability to guarantee social policies. Alongside the diversity of the socio-political, juridical and normative framework (Defourny and Borzaga, 2001) and the coexistence of multiple organizational models (Evers and Laville, 2004), the academic debate within some research institutes, but especially the European Research Network (EMES), has contributed to providing some theoretical unity to the social economy.

According to the normative criteria, the organizations that belong to the social economy are those that incorporate certain principles in their internal structure and objectives, including (1) the goal of serving the community and social interests rather than the interests of capital, (2) a management structure that is independent of and separate from both the public and the private sectors, (3) the democratic nature of decisionmaking processes, the ultimate expression of which is the motto 'one 
person, one vote'; and (4) the primacy of people and of labor over capital in the distribution of income.

According to EMES, the concept of social entrepreneurship is part of the new dynamics of the third sector that reveals the emergence of innovative configurations in the social sector: the social enterprises. Defourny and Borgaza (2001) claim it is the combination of the characteristic elements of European cooperative and the North American non-profit sector that confer social enterprises the social entrepreneurial dynamic. They are private and independent organizations that continuously provide products and services and which have a high economic risk and a minimum amount of paid work. Their main objective is to benefit the community. Galera refers to the importance of alternative organizational forms as being 'traced back to the so-called third sector, social economy or more recently social enterprise concept, depending on the particular approach and tradition adopted' (2001: 23).

Unlike the North American perspective, the European perspective emphasizes the internal and external organizational mechanisms that, following a participative management strategy guided by a diversity of stakeholders, assures the attainment of social goals in accordance with democratic principles of governance (Defourny and Borzaga, 2001; Defourny and Nyssens, 2010b).

In consistency with these principles and values, throughout the 1990s, the concept of solidarity economy emerged in the Francophone context, again in opposition to the set of traditional social economy organizations, putting forth new institutional solutions that integrated new perspectives on collaborative work intervention methodologies (Quintão, 2004). Adapted to the reality of different countries, particularly in Latin America and in the global semi-periphery, solidarity economics expressed itself 'through the socialization of productive resources and the adoption of equalitarian criteria' (Laville and Gaiger, 2009: 162), with a double dimension: political and economic (Laville, 2009). It is an approach that promotes civic, democratic, participative and economically pluralist projects as alternatives to the public and private sectors through such economic principles and redistribution, reciprocity and barter, using both monetary and non-monetary resources (Quintão, 2004) based on ideas of solidarity over individual interests and material profit.

Therefore, it appears there is a convergent movement between both theories as a result of socioeconomic changes, particularly with the emergence of the social enterprise in some European countries, and of similar initiatives in the countries of Latin America (Ferreira, 2005), which identify a set of economic activities of a social nature in parallel with a political project to establish a more cohesive alternative society (Morais, 2007).

The important role of these academic traditions and practices in contextualizing, developing and encouraging reflection on the question of social entrepreneurship is unquestionable. They place them on the political agenda and contribute to the dynamism of third sector 
organizations. However, one must also add that the diversity of sectoral and geographical contexts in which they have occurred has also contributed to the differences within the concept.

Emerging from these debates is the critical importance of organizational sustainability, particularly financial sustainability. On the pretext of the need to adopt a new attitude towards business and profit, the logic of the market seems to impose itself at various levels - from the goals of social projects to the management strategies, including the type of rhetoric used (Dart, 2004). However, these notions can give rise to various tensions within and between the different schools of thought. Or it may even lead some to question the need for restrictions to be imposed on the distribution and appropriation of profits generated by the enterprise due to the often justified threat this may impinge on its social mission (Yunus, 2011).

\section{Social entrepreneurship in Portugal: Defining the field and the key actors}

The aim of this article is to define and discuss the different perspectives of social entrepreneurship that the key actors in the third sector in Portugal display. To frame the analysis we used Mair and Marti's generic definition of social entrepreneurship as a 'process involving the innovative use and combination of resources to ... address social needs' (2006: 37). It seeks to explore a range of possible configurations through the underlying continuum proposed by Dees (2001) with, at one extreme, those closest to the philanthropic model and at the other extreme, the social enterprise models that use similar management tools to those employed by for-profit organizations which have different principles and values. Between these extremes there is plenty of space for hybrid organizations with many different degrees of social entrepreneurship.

Within the European context, Portugal is no exception in terms of the imprecisions and ambiguities of social entrepreneurship or its field of action or in terms of the social and academic debates on the concept of the third sector, the social economy and, more recently, of social enterprise (Perista, 2001; Quintão, 2004, 2011; Amaro, 2009; Ferreiro, 2011; Ferreira, 2006. Ferreiro (2011), for instance, labels the social economy as the "other economy", where alternative economic activities are not confined to the conventional governance mechanisms of the State and Market. Social economy is characterized by responses that reconcile sustainability and cooperation, solidarity and democratic governance. This perspective is directly influenced by the assumptions of the European school of thought. Another concept that is gaining popularity among Portuguese authors is that of Solidarity Economy. Amaro (2009) reckons that the solidarity economy relies on the principle of solidarity throughout a set of dimensions, of which we highlight the economic (combination of state, market and community), the social (directed to the most vulnerable social groups), the territorial (community-based) and the political (internal and external democracy). On the other hand, social entrepreneurship concept is used 
mainly by Ferreira (2006) that frames it within the American school of thought. The author considers that it combines an individual component, illustrated by the role of social entrepreneurs, and a collective component, that takes the form of social enterprises. This approach is inspired by the innovative nature that stems from the classic entrepreneurship literatures. In this case, the main difference is the pursuit and primacy of a social mission.

While these concepts are not exactly overlapping realities, they are more or less convergent conceptual frameworks that focus on bodies that do not subscribe the profit-making logic of the market. If the group of organizations that form the social economy are composed of associations, cooperatives, mutual societies and foundations (Chaves and MonzónCampos, 2008), the third sector has been a meeting place between the social economy and the non-profit sector, enabling greater hybridization of initiatives (CIRIEC, 2007) . The nonprofit sector excludes mutual societies and cooperatives, and in Europe there are some reserves about the inclusion of commercial cooperatives and mutual societies linked to banking and insurance in the social and solidarity economies (Chaves and MonzónCampos, 2008; Carvalho, 2010).

The third sector can be viewed as an adequate interface for social entrepreneurship initiatives to flourish given its heuristic potential, and a well-known diversity of organizational formats (Quintão, 2011). Among the main characteristics of the third sector in Portugal we highlight the reliance on public funding, the weight of religious and welfare entities, the need for training and the professionalization of the sector, the absence of a dynamic civil society and the lack of collective action (Franco et al., 2005). These factors, and the inexistence or the fragmented nature of the legislation framing the third sector in Portugal, can help explain its lack of recognition and autonomy.

The diffusion of the many concepts in part reveals the fragility of this field at the international level, as observed above, and Portugal is no exception. In fact, one can identify some transformations during the 1980s, that translated into an increase in the number of organizations, a diversity of its legal forms and operating areas, the creation and development of platforms, networks and governing bodies. They constitute the representative structures of the third sector base organizations which emerge in specific historical and political contexts after the fall of the dictatorship. These governing bodies have been chosen as the key actors to be analysed here, because they share the same fundamental principles governing this sector.

In an effort to establish a temporal line to show the formal constitution of these governing bodies that will be a clear indicator of the importance of the third sector in Portugal, we note the creation of the Portuguese Union of Charities in 1976 and the Portuguese Union of Mutual Societies and the IPSS during the 1980s. The 1980s also saw the birth of the Portuguese Platform of Non-Governmental Development Organizations, the National Federation of Social Solidarity Cooperatives and the Portuguese Cooperative Confederation. During the 1990s the Portuguese Foundations Center 
and the Portuguese Association for Local Development and the European Anti-Poverty Network-Portugal were formed. In 2010 CASES was created as the public representative of the third sector in Portugal and which seeks to 'promote and support that social entrepreneurship that stimulates the entrepreneurial spirit of the people and organizations through a strategy of sustainable development' (CASES, 2011).

The portuguese third sector is characterized by an overwhelming strong presence of traditional Social Economy organizational frameworks, namely associations, institutions of social solidarity (IPSS), cooperatives, foundations and mutual societies (Perista, 2001; Hespanha, 2000; Parente, 2011; Quintão, 2011, Carvalho, 2011). Figure 1, was constructed by Quintão (2011) and presents a rough outline of the third sector today but it is neither complete nor numerically precise due to the vast number of sources this would entail. In Figure 1 we can see represented a variety of organizations, some of which are more traditional and others more recent (Parente, 2011: 264). Despite the numeric importance of social and

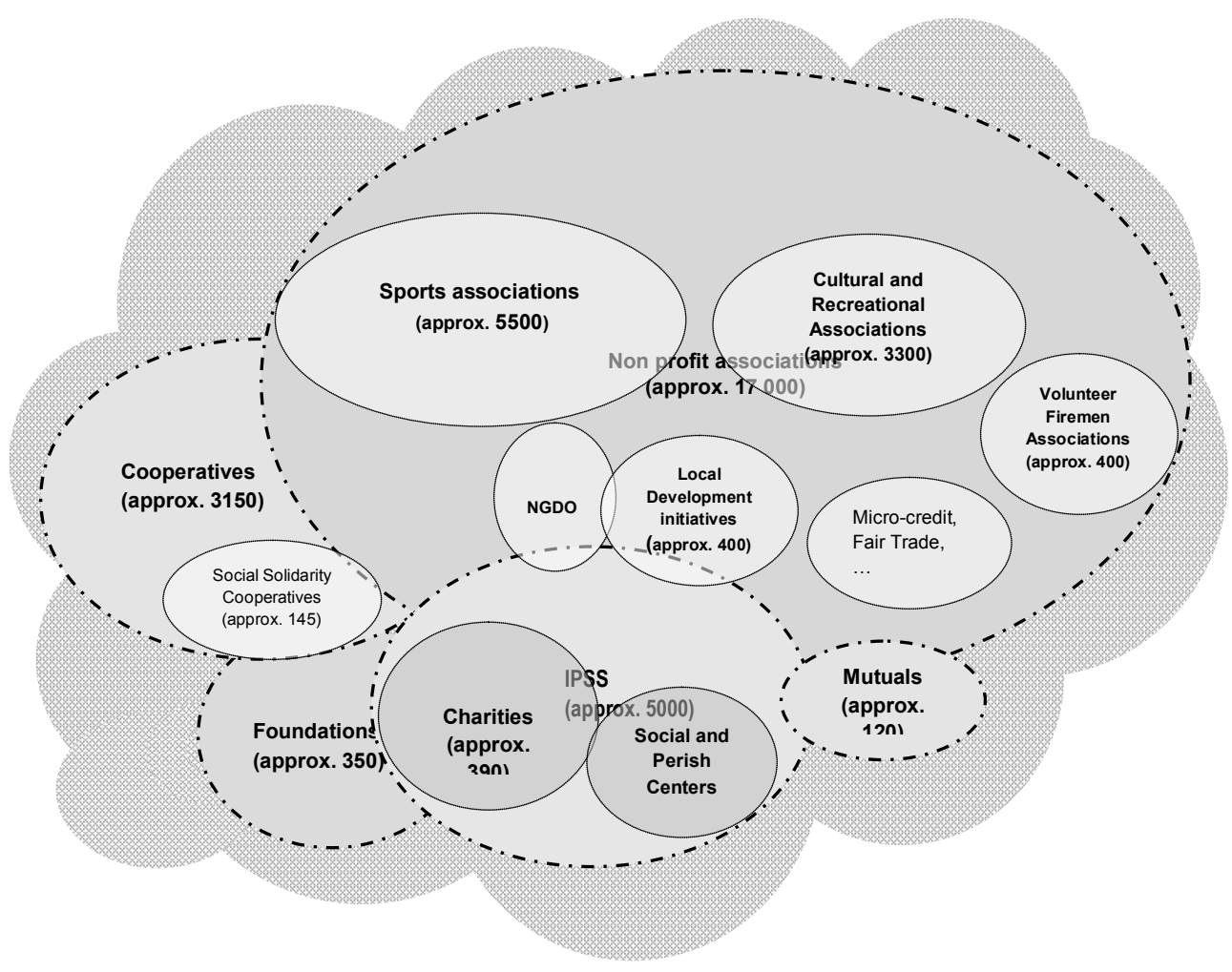

Figure 1. The third sector in Portugal: an overview Source: Quintão (2011). 
religious organizations, we cannot neglect the growth of new entities that address new social challenges, such as the environment, local development, human rights, etc. Nevertheless, according to a comparative study on the Portuguese nonprofit sector within the international context (Salamon, et al., 2012), in 2006 it was characterized by "the unusually large share of organizations that provide social assistance" (Salamon, et al., 2012: 8).

In the key actors' selection, we considered the sector's diversity, and its numeric importance, along with the specificities of the social actors directly involved in the promotion of social entrepreneurship. Thus, the umbrella entities of different juridical and organizational forms were interviewed as well as the emergent entities connected to the promotion and development of social entrepreneurship.

In this way the third sector has gradually assumed an important position to the extent that it generates employment and promotes the strengthening of the national economy through the provision of goods, product and services. "In 2006, nonprofit institutions (NPI) in Portugal employed nearly 185,000 workers [and] The workers produced goods and services worth over $€ 5.7$ billion, and ultimately contributed $€ 2.7$ billion of Gross Value Added to the national economy" (Salamon, et. at, 2012: 4). Taking the diversity of the statutes and areas of activity, it is through this type of actor that we seek to capture the perspectives of social entrepreneurship.

\section{Methodology}

The priority of this study was to interview the key actors actually operating within the third sector, both as institutions and as social actors. The purpose of the interviews were: 1) to understand the interviewees' perspectives on social entrepreneurship and its main principles; 2) to identify the applicability of the concept of social entrepreneurship within the organizational context and 3) to acknowledge the interviewees' representations on the use of other concepts in addition to social entrepreneurship.

We conducted a total of 20 semistructured interviews. ${ }^{1}$ The transcripts of the interviews were subjected to a content analysis based on the classical thematic coding procedure (Straus, 1987, cited in Flick 1998). Of these, 18 interviewees were from representative institutions and national political programmes and two were individual key actors. Table 1 shows the organizations and individuals organized according to their area of activity and the organizations' legal status.

Of the 18 institutional interviewees, eight were chosen because they are top level actors, meaning they are part of representative bodies of the various legal forms and organizations that make up the third sector in Portugal. Following Cerdeira and Padilha's sectoral structure typology (1988), Organization D was interviewed as occupying the third level of the third sector. The organizations representing bodies that make up this sectoral structure and which occupy the intermediate level in the hierarchy of institutional perspectives, 
organizations A, B, C, E, F, G, M and $\mathrm{H}$ were interviewed, with the latter of these operating at the regional level and representing different subsectors within the third sector.

The grassroots organizations occupy the primary level, and from them we interviewed two research and training centres - organizations I and $\mathrm{J}$ - chosen due to their importance to the study and the specialized training they provide in the field of social entrepreneurship. Another grassroots organization - Organization $\mathrm{K}$ was identified for placing the question of social innovation on its national agenda, while Organization L was chosen as the only financial agency operating within the third sector and, finally, Organization $\mathrm{N}$ was chosen as the only organization promoting the social economy in education at the secondary school level.

In addition to these sectoral representation bodies, two key actors were chosen as representatives of state policy-Political representatives 1 and 2 - and two representatives of national programmes related to the development and training of social entrepreneurship processes: Programme 1 (programme for policies to combat poverty and social exclusion); and Programme 2 (programme for the elimination

Table 1. Key actors interviewed according to field of activity and legal status

\begin{tabular}{|c|c|c|}
\hline $\begin{array}{l}\text { Organizational and } \\
\text { individual key actors }\end{array}$ & Field of activity & Legal status \\
\hline Organization A & \multirow{8}{*}{$\begin{array}{l}\text { Sectoral umbrella } \\
\text { organizations }\end{array}$} & Private non-profit \\
\hline Organization B & & Civil and canonical association \\
\hline Organization $\mathrm{C}$ & & Mutual society \\
\hline Organization D & & Cooperative confederation \\
\hline Organization E & & Non-profit public interest private organization \\
\hline Organization $\mathrm{F}$ & & Non-profit public interest private organization \\
\hline Organization $\mathrm{G}$ & & Non-profit development association \\
\hline Organization $\mathrm{H}$ & & Non-profit association \\
\hline Political representative 1 & \multirow{2}{*}{ State } & Public cooperative \\
\hline Political representative 2 & & Public institute \\
\hline Organization I & \multirow{3}{*}{ Research and education } & Research and education organization \\
\hline Organization $\mathrm{J}$ & & European Scientific Research Network \\
\hline Organization $\mathrm{K}$ & & Private non-profit association \\
\hline Programme 1 & \multirow{4}{*}{$\begin{array}{l}\text { Representatives of } \\
\text { political programmes/ } \\
\text { development institutions }\end{array}$} & $\begin{array}{l}\text { Political programme in the area of combating } \\
\text { poverty and social exclusion }\end{array}$ \\
\hline Programme 2 & & $\begin{array}{l}\text { Political programme in the area of the } \\
\text { combatting inequality }\end{array}$ \\
\hline Organization L & & Non-governmental non-profit organization \\
\hline Organization $\mathrm{M}$ & & Social solidarity association \\
\hline Organization $\mathrm{N}$ & \multirow{3}{*}{$\begin{array}{l}\text { Institutions and actors } \\
\text { related to education } \\
\text { sector }\end{array}$} & Education cooperative \\
\hline Informant 1 & & a) \\
\hline Informant 2 & & a) \\
\hline
\end{tabular}

Source: Authors' data.

a) Individuals without legal status. 
of factors that cause inequality and discrimination in access to the labor market). The individual actors interviewed-Informant 1 and 2 were chosen for their experience working as interlocutors and consultants in the area of social entrepreneurship and for their current positions as university lecturers working on scientific programmes related to social entrepreneurship.

\section{Empirical Evidence}

\section{The concepts of social entrepreneurship}

In this section we sought to understand what social entrepreneurship means to the interviewees as well as its main characteristics. Afterwards we will identify the applicability of this concept within the organizational context, asking if the concept is used in the interviewees' institution and if they prefer or relate more with others concepts, such as social economy, solidarity economy, third sector or other concepts.

During the early analysis of 20 interviewees, 11 (Organizations F, H, I, J, K, L and M, Political representative 1 , Informants 1 and 2, and Political programme 2) were familiar with the concept and directly related it with the school of social innovation. The remainder were divided between those who did not know, were unfamiliar with the concept or who were uncertain (Organizations D and N) and those who chose other conceptual types - some closer to the business school model (Organization A and Political representative 2) and other closer to the social innovation model, although more diverse in terms of its

Table 2. Key actors by theoretical reference

\begin{tabular}{|c|c|c|c|}
\hline Theoretical reference & \multicolumn{2}{|c|}{ Key actors' identification } & $\mathrm{N}$ \\
\hline \multirow{2}{*}{ Social innovation school } & $\begin{array}{l}\text { Ideal type } \\
\text { interpretation }\end{array}$ & $\begin{array}{l}\text { Organizations I, K, L and } \\
\text { Informants } 1 \text { and } 2\end{array}$ & 5 \\
\hline & $\begin{array}{l}\text { Interpretation that } \\
\text { deviated from the } \\
\text { ideal type }\end{array}$ & $\begin{array}{l}\text { Organizations } \mathrm{J}, \mathrm{F}, \mathrm{H}, \mathrm{M}, \\
\text { Political representative } 1 \text { and } \\
\text { Political programme } 2\end{array}$ & 6 \\
\hline Business school & \multicolumn{2}{|c|}{ Organization A and Political representative 2} & 2 \\
\hline Other theoretical references & \multicolumn{2}{|c|}{ Organizations B, C, E, G and Political programme 1} & 5 \\
\hline No theoretical reference & \multicolumn{2}{|c|}{ Organizations $\mathrm{D}$ and $\mathrm{N}$} & 2 \\
\hline
\end{tabular}


characteristics, which differed from the ideal type (Organizations B, C, E and G, and Political programme 1) (Table 2).

As a whole, and despite variations in the degree of familiarity with the theme, seven cases mentioned the concept's lack of a precise definition and/or theoretical unity (Organizations D, I, J, K and N, and Political programmes 1 and 2), with eight respondents describing it as a recent phenomenon (Programme 2, Organizations A, E, F, I and M, and Political representatives 1 and 2). The cross-cutting nature of the impressions closest to the social innovation school identifies and highlights the role of the social entrepreneur, which assumes special importance in Organizations G, I, J, K and L, Political representative 1 and Informant 1 . It is also important to note the particular importance Organizations B, E, F, I, K and L, Political programmes 1 and 2, and Informant 1 attribute to social entrepreneurship in promoting local development and the community empowerment (Table 3). Below we will explore some of these representation typologies.

Table 3. Aspects of social entrepreneurship more stated by the key actors

\begin{tabular}{|l|l|l|}
\hline Aspects & Key actors & N \\
\hline $\begin{array}{l}\text { Social entrepreneurship as } \\
\text { a recent phenomenon }\end{array}$ & $\begin{array}{l}\text { Programme 2, Organizations A, E, F, I, M and } \\
\text { Political representatives 1 and 2 }\end{array}$ & 8 \\
\hline $\begin{array}{l}\text { Role of the social } \\
\text { entrepreneur }\end{array}$ & $\begin{array}{l}\text { Organizations G, I, J, K, L, Political representative 1 } \\
\text { and Informant 1 }\end{array}$ & 7 \\
\hline $\begin{array}{l}\text { Local development and } \\
\text { the empowerment of } \\
\text { communities }\end{array}$ & $\begin{array}{l}\text { Organizations B, E, F, I, K, L, Political programmes } \\
1 \text { and 2 and Informant 1 }\end{array}$ & 9 \\
\hline $\begin{array}{l}\text { Absence of theoretical } \\
\text { reference }\end{array}$ & $\begin{array}{l}\text { Organizations D, I, J, K, N and Political } \\
\text { programmes 1 and 2 }\end{array}$ & 7 \\
\hline
\end{tabular}

\section{Perspectives associated with the social} innovation ideal type

Of the 11 cases that were placed within the social innovation current, five (Organizations $\mathrm{I}, \mathrm{K}$ and $\mathrm{L}$, and Informants 1 and 2) reveal a close association with this school, particularly with its characteristics: social innovation, sustainability, scale, impact and social mission. This affinity can be measured by the type of goals these institutions pursue, and by the projects the individual actors develop within the field of social entrepreneurship. Here are some illustrative excerpts:

It consists in finding ways to respond to social needs that are entirely or partially sustainable economically..., small-scale actions that can be expanded later, from the bottom-up and that are based on empowerment (Informant 1).

We can quickly identify when there is a worthwhile social entrepreneurial initiative... there are five or six elements... to empower the beneficiaries so 
they can be part of the solution and ensure it is sustainable over the long term...to have a strongly social mission... The goal cannot be to make a profit, although there can be concern to make money to reinvest in the mission...It must be innovative: that is, listening to and observing what is going on, bringing in people with new ideas and seeking to change the way in which things are done...that is part of its spread and replication/then there's the part when they expand and replicate. (Organization I).

From a closer analysis of some of these excerpts we see that for Organization L the social entrepreneur assumes the role of innovator: "[the social entrepreneur] is able to look at the situation in a systematic way and map out where the problems begin and act on the causes'. This individual-centred approach is reinforced by the abilities associated with the social entrepreneur - 'creative, strategic, entrepreneurial, but who puts these skills at the service of a social objective' - characteristics that determine the success of social entrepreneurship.

The sustainability aspect was noted by Informant 1. Social, cultural, environmental and economic sustainability are criteria for social entrepreneurship initiatives. The question of sustainability was also mentioned by Informant 2 who noted/viewed the concept through the application of management tools by third sector organizations, for example, by ensuring the efficient use of resources and assessing impacts and responsibilities, in order to achieve greater social and environmental impact.

\section{Perspectives that deviate from the social innovation ideal type}

While the cases described above are more typical of the logic and characteristics of social innovation, Political representative 1, Organizations $\mathrm{F}, \mathrm{H}, \mathrm{J}$ and $\mathrm{M}$, and Political programme 2 demonstrate interpretations that are close to this school, but with more fragmented elements and with some peculiarities. In the majority of these cases the concept is translated by one or more particular dimensions, while never assuming the global of its dimensions.

By the legal status of these organizations and the nature of their operations, it is possible to observe the existence of proximities with the social economy school and non-profit bodies (in the case of Organizations $\mathrm{H}$ and $\mathrm{M}$ ), although it is important to emphasis the role that those interviewed and the leaders of these organizations seem to fulfil. For example, in the case of Political representative 1, social entrepreneurship manifests itself through its capacity for innovation, which is described as 'the resolution of social problems, preferably in an innovative way both in terms of solution and in terms of method'. For Organization F, the concept is defined as 'all manner of initiatives that result from the response of communities to their own problems'. In this way an association is established with the prospect of creating, innovating and introducing a new dynamic, with emphasis later being placed on the role and nature of the social entrepreneur as the motivator who manages the needs and consequent opportunities, implying a commitment between the 
recipients of the activities and the entrepreneurial agent.

Added to this is the importance of protecting the more particular character of some of these interpretations. For example, Organization J offered two readings of the concept. If, on the one hand it understood social entrepreneurship meant the creation of self-employment or the creation of one's own business (which the interviewee called 'inclusive' entrepreneurship), on the other it confirmed that it is a response to social needs that are not being met by either the private or the public sector. This interpretation leans towards an analysis that is more focused on the individual actor, even though organizations can be a means for developing the projects of social entrepreneurship. Innovation, proactivity, scale, sustainability, creation of social value and risk are all emphasized.

Organization $\mathrm{C}$ also shares this focus on the individual, although it also notes two aspects of the concept: (1) the social, which is associated with individual action; and (2) the collective, which is connected with a group. The distinction between these is related to the target audience, that is to say, whether or not the members of that audience are beneficiaries. Mutual societies and cooperatives, organizations in which the members are beneficiaries, are considered collective entrepreneurship. More generically, the problematic is understood as an individual or collective process conducive to behavioural change that attends to new necessities and opportunities. Revealing a proximity to the normative view of the social economy, Organization C mentioned the importance of the model of governance based on democratic principles, through internal election processes or accountability mechanisms, in the everyday operations that aim for the fulfilment of the organization's mission.

Political programme 2 offered a slightly different view of these concepts. As a result of the nature of its projects, the promotion of individual empowerment and the struggle against inequality, this actor revealed a notion that was closer to classical theories of entrepreneurship which propose its object should be an instrument of policymaking to combat unemployment. In its opinion, social entrepreneurship is 'the ability to develop entrepreneurship in disadvantaged individuals, who by themselves are incapable of being entrepreneurs'.

To these perspectives we can add two themes that are strongly associated with North American schools of thought. Firstly, noted by Organizations $\mathrm{H}$, I and $\mathrm{J}$, and like the social innovation school, is the assumption that social entrepreneurship intersects with other sectors. Organization I believed there is no need for social entrepreneurship within an entire organization: it could be in just one project. That being so, this organization introduces the term social 'intrapreneurship' to shed light on socially entrepreneurial initiatives that take place within an organization that does not even have to have a social mission. Secondly, at least for four interviewees (Organizations C, I, L and $\mathrm{M})$, profit is an inherent part of social entrepreneurship as it is a necessary condition to guarantee the sustainability of the social mission. For Organization 
L, social enterprise extends to organizations in which profits are not individually appropriated but 'revert to a community, an association... the money is permanently invested and as a very clear social purpose'. Organization $\mathrm{C}$ attacked the idea nonprofit organizations should not be sustainable or profitable. Profits are a means of achieving a goal, which in this case represent some kind of investment that is useful for its members and/or for the larger community.

The applicability of the concept of social entrepreneurship and identification of other concepts

In order to understand the framework of the perspectives of social entrepreneurship within the sweep of broader ideas relating to the third sector, the key actors were questioned about (1) the applicability of this concept within the organizational domain, including projects and, in the case of individuals, according to their experiences in the area; and (2) if there are other concepts with which they are more identified attending the social mission. Generally speaking, they all apply_at least partially_some of the dimensions and practices of social entrepreneurship. Only five actors (Organizations A, D, J, M and N) said they did not directly apply the concept, despite believing that the organizational practices and discourses reflect and incorporate some of its characteristics. As we shall see below, we could verify that these are organizations that, on the one hand, announced their lack of familiarity with the theme and, on the other, revealed their close relationship with other concepts.
It is therefore necessary to understand which concepts, in addition to social entrepreneurship, are frequently favoured and have greater weight in the discourse of these actors. Generally speaking, the problematic of social economy and solidarity economy, of the third sector and of social innovation appear frequently in their responses. However, it is important to note that at least seven cases (Political representative 2, Political programme 2, and Organizations B, $\mathrm{H}$, $\mathrm{J}, \mathrm{K}$ and $\mathrm{N}$ ) admit to having difficulty distinguishing social entrepreneurship from other concepts, particularly from classical entrepreneurship and social innovation.

Social entrepreneurship is different from, let us say, general or private entrepreneurship. It has a different appearance because its organizational and procedural aims and objectives are different in terms of its purpose. One is created as a business to earn money, the other created from a perspective of social opportunity: that is to say, it is an attempt to resolve some social need (Organization C).

I cannot differentiate 100 per cent between the concepts of social innovation and social entrepreneurship. I think an initiative that promotes social innovation must be entrepreneurial... another component that perhaps distinguishes social entrepreneurship from innovation has to do with risk, with the assumption of risk (Organization $\mathrm{H})$.

Another concept that appears frequently in the speeches of key actors 
and against which there is some doubt is that of corporate social responsibility, the ambiguity and mistrust of which seems to elicite becomes quite clear in the following excerpt.

\begin{abstract}
Any company in which social responsibility is part of its obligations, that develops entrepreneurial projects, that is innovative, that addresses some of the community's needs and which stirs up some potential that was undervalued, is also entrepreneurial. That is a fact. However, I do not think corporate social responsibility is so... When companies move forward with a CSR project, their sole aim is to improve their image and, by doing so, win more clients (Organization B)
\end{abstract}

The interconnections between social entrepreneurship and social responsibility are also established by Informant 2, to the extent that they view social entrepreneurship as a means of achieving social responsibility, strategically and over the long term.

While there is a debate about these definitions, it is the concepts of social economy, solidarity economy and the third sector that are the greatest competitors - at least in the panorama of Portuguese dynamics - with the concept of social entrepreneurship. While some cases refer to the difficulties in distinguishing between these concepts (Political programme 2), some (Organizations E and $G$ ) consider them to be complementary, while others still state that they do not use the social entrepreneurship concept, preferring social economy as the more appropriate (Organizations $\mathrm{C}, \mathrm{D}, \mathrm{J}$ and $\mathrm{N}$ ). Added to these are the cases of Political representative 1 and Organizations $\mathrm{F}$ and $\mathrm{K}$, which prefer solidarity economy. We further note the preference for the application of third system concepts by part of Organization B and of the third sector by Organization M (Table 4).

Table 4. Conceptual position of key actors

\begin{tabular}{|l|l|l|}
\hline Concept & Key actors & N \\
\hline Social economy & Organizations C, D, J and N & 4 \\
\hline Solidarity economy & $\begin{array}{l}\text { Political representative 1 } \\
\text { Organizations F and K }\end{array}$ & 3 \\
\hline Third sector & Organization M & 1 \\
\hline Third system & Organization B & 1 \\
\hline Difficulty of positioning & $\begin{array}{l}\text { Organization A and Political } \\
\text { representative 2 }\end{array}$ \\
\hline
\end{tabular}

Source: Authors' data. 
The difficulty some interviewees had in positioning themselves in respect of the concept is also noted, as in the cases of Political representative 2 and Organization A.

As for the influence of the European social economy school in the Portuguese context, there is a set of organizations that choose this concept over all others. Among them are Organizations $\mathrm{C}, \mathrm{D}, \mathrm{J}$ and $\mathrm{N}$, actors that in terms of legal form are mainly cooperatives and mutual societies, and that in terms of goals fit perfectly into the social economy matrix. Here are some illustrative excerpts:

We do not see the social economy as the economics of the poor... The social economy includes all those institutions with certain common characteristics, regardless of the few differences that exist between them (Organization D).

A set of organizations the nature of which can be described as being 'one member, one vote'; they are non-profit making organizations, democratically managed organizations with institutional autonomy (Organization N).

For the mutual society that is Organization C: 'mutual societies continue to place themselves within the social economy' to the extent that mutualism is based on the egalitarian ideal through which individuals organize themselves in order to address problems within their communities. Organization J noted the caution required in interpreting ideas, calling attention to the Johns Hopkins University's definition of 'non-profit organizations', which distorts the idea of the social sector by excluding mutual societies and cooperatives and to including others that fall beyond the scope of social economy.

As we can see below, another group of organizations expressed their preference for the notion of solidarity economy:

The commitment to solidarity, which to me is fundamental, does not fit...within the concept of the social economy. When I speak of the solidarity economy, the first thing that comes to my mind, apart from the word 'economy', is the central role that solidarity has within the framework of our human relations and the satisfaction of our needs, (Organization F).

The social economy was born in order to address those social problems the market does not solve....and is almost entirely dependent on the state for funding... The solidarity economy is both older and independent of the state...it has very close links with civil society, as well as with the market and with the state (Political representative 1).

Organization B distinguished the solidarity economy from the social economy by inserting the former into the latter. According to this organization the solidarity economy includes the IPSS and the welfare charities, which seek to satisfy the social needs of the community in general. The social economy includes the cooperatives and mutual societies that seek to defend the specific interests of their members. However, the solidarity economy concept is interpreted differently several other 
interviewees, which is a demonstration of its weak consolidation within the field. Running across this problematic is the concept of the third sector, which, as we will see, enjoys no consensus among the organizations:

Thrown into the third sector concept is a set of institutions that according to our categorization should not be there because they are organizations that stand on the fringes, between the public and the private sectors and organizations that stand somewhere between the private sector and cooperatives (Organization N).

The dubious character associated with third sector organizations is a result, according to Organization N, of the lack of an appropriate legal status that is able to define their practices and areas of activity. Because of this, organizations within the social and solidarity economies are incorporated into the third sector. On the other hand, as depicted by Informant 1 and Organization $\mathrm{C}$, this situation can be justified by the enormous diversity of third sector organizations, not only in legal terms, but especially as a result of the different principles that govern them, which results in a lack of a common sense of identity. For the representative of Political programme 2 , the heterogeneity of this sector is its greatest strength and 'simultaneously its weakness because there is a need for affirmation before the other economy, the dominant economy'. The need to establish a common designation that will encourage the emergence of a sense of belonging within the various organizations was also noted.

Because it believes the plurality of organizations here involved means the unity of a 'sector' is not possible, Organization B stressed its preference for the term 'third system' (Lloyd, 2004; Estivill, 2008). For Informant 2 and Political programme 1, the third sector is an all-encompassing concept, covering social and solidarity economy, and according to Informant 2, social economy is an economic 'type' applied to the third sector. While Organization $M$ also applied the labels social economy and solidarity economy, it noted that as a result of the organizational question it identifies more with the third sector concept. Underlying the organizational question is the notion that social entrepreneurship is 'more informal, or that it does not have to comply with a legal status'.

Finally, we demonstrate the complementarity that three organizations (E, F and $\mathrm{G}$ ) confer of the different concepts:
In my opinion the concepts are not the same thing, but they are complementary-I believe social entrepreneurship is part of the large cake that is the social economy (Organization E).

Informant 1 described the distinction they made between social entrepreneurship and the social economy, claiming that this is an economic response model in which economic activity is developed with consideration for environmental, social and cultural sustainability, and in which social entrepreneurship constitutes a social response that strives to be economically sustainable. Recalling Dees' continuum (2001), this interviewee recognized the presence 
of 'a series of hybrids... [in which] the social economy is closest to economic activity and social entrepreneurship is closest to purely social activity... However, they are spots that at the same time have points of intersection'.

\section{Conclusion}

The aim of this article was to identify and discuss the different key actors' perspectives of social entrepreneurship in Portugal, taking as its foundation the more internationally widespread approaches from the North American, European and Latin American academic traditions.

During recent years this theme has assumed greater importance among public and political organizations, grassroots initiatives and organizations, and umbrella organizations of the third sector, media and scientific community.

Despite the increasing importance of the phenomenon, this analysis has provided evidence of the lack of unity in Portugal regarding the definition of social entrepreneurship.

However, there is an approximation between the responses of those interviewed to the concepts and scale of analysis postulated by theoretical currents within the North American school, especially social innovation, and particularly the following characterizing elements: (i) the emphasis that is placed on the individual figure of the entrepreneur; (ii) the concern to ensure the financial sustainability of the organizations and initiatives; (ii) the importance of empowering communities; (iv) the search for innovative solutions to social problems; and (v) the applicability of the concept to the various sectors of economic activity.

When asked about alternatives, nine of the 20 respondents stated their preference for other concepts, and for social economy and solidarity economy in particular, which is also an indicator of the lack of theoretical and conceptual definitions and to the fact the term 'social entrepreneurship' is in itself relatively recent.

The limited consensual nature of these concepts and the dispersion of Portuguese legislation on the third sectoringeneral haveimplications on its economic sustainability, and conditions recognition and development of its activities. However, this sector of activity, constituted by a panoply of organizations with diverse statutes, legal status and organizational and management set-ups, has developed a range of social entrepreneurial practices. It is acknowledged that the result of the confrontation between the many theoretical currents and the representations of the key interlocutors interviewed may represent a fundamental contribution towards shaping the reflective structure of the field in which uncertainty, ignorance and a lack of agreed references concerning the concept in Portugal have prevailed.

The recorded views of the key actors contribute to the debate and towards the shaping of the phenomenon at the national level, inspired by international approaches.

\section{Note}

1 There were more than 20 interviewees because some interviews had more than one interviewee. 


\section{References}

Amaro, R. (2009) 'A Economia Solidária da Macaronésia - Um Novo Conceito'. Revista de Economia Solidária. 1:11-28.

Alvord, S., D. Brown and C. Letts (2003) Social Entrepreneurship: Leadership that Facilitates Societal Transformation - An Exploratory Study. Center for Public Leadership Working Paper Series, 3 (5).

Anderson, B.B. and G. Dees (2006) Rhetoric, 'Reality and Research: Building a Solid Foundation for the Practice of Social Entrepreneurship' In Nicholls, A. (ed.), Social Entrepreneurship: New Models of Sustainable Social Change, pp. 56-73. Oxford: Oxford University Press.

Bornstein, D. (2007) Como Mudar o Mundo: Os Empreendedores Sociais e o Poder de Novas Ideias. Alfragide: EstrelaPolar.

Boschee, J. and J. McClurg (2003) Towards a Better Understanding of Social Entrepreneurship: Some Important Distinctions. Social Enterprise Alliance working paper.

Carvalho, A. (2010) 'Quantifying the third sector in Portugal: an overview and evolution from 1997 to 2007.' Voluntas, International Journal of Voluntary and Nonprofit Organizations. ISTR - International Society for Third Sector Research, 21(4): 588-610

CASES (2011) Quem Somos. www.cases.pt/sobre-nos/quem-somos (consulted 11 December 2011)

Cerdeira, M.C. and M. E. Padilha (1988) As Estruturas Sindicais Portuguesas:

Uma Análise Evolutiva, 1933-Abril 1984. Lisbon: Ministério do Emprego e da Segurança Social.

Chaves, R. and J. L. Monzón-Campos (2008) The Social Economy in the European Union Brussels: CIRIEC No. 2008/02.

CIRIEC (2000) The enterprises and organizations of the third system. A strategic challenge for employment. Liège: CIRIEC-International.

CIRIEC (2007) A Economia Social na União Europeia. Síntese do relatório elaborado a pedido do Comité Económico e Social Europeu (CESE) pelo Centro Internacional de Pesquisa e Informação sobre Economia Pública, Social e Cooperativa (CIRIEC). Bruxels: Portugal Commission DGV.

Dart, R. (2004) 'Being "Business-Like" in a Non-profit Organization: A Grounded and Inductive Typology' Nonprofit and Voluntary Sector Quarterly, 33:290-310. Dees, G. (2001) 'The Meaning of Social Entrepreneurship', www.caseatduke.org/ documents/dees_sedef.pdf (consulted 10 November 2011).

Dees, G. and B. Anderson (2006) 'Framing a Theory of Social Entrepreneurship: Building on two Schools of Practice and Thought', Business, 1:39-66.

Defourny, J. and C. Borzaga (eds.) (2001) The Emergence of Social Enterprise.

London: Routledge.

Defourny, J. and M. Nyssens (2010a) 'Conceptions of Social Enterprise and Social Entrepreneurship in Europe and the United States: Convergences and Divergences', Journal of Social Entrepreneurship, 1(1):32-53.

Defourny, J. and M. Nyssens (2010b) 'Social Enterprise in Europe: At the Crossroads of Market, Public Policies and Third Sector'. Policy and Society, 29:23142.

Emerson, J. and F. Twersky (eds.) (1996) New Social Entrepreneurs: The Success, Challenge and Lessons of Non-profit Enterprise Creation, San Francisco, CA: 
Roberts Foundation, Homeless Economic Development Fund.

Evers, A. and J.-L. Laville (2004) 'Defining the Third Sector in Europe' In Evers, A. and J.-L. Laville (eds.) The Third Sector in Europe, pp. 11-42. London: Edward Elgar.

Ferreira, S. (2006) 'A Economia Social Face ao Mercado - O Empreendedorismo Social' In Almeida, M. A., Nunes, S. Pais and T. P. Amaro (ed.) - Conferência Nacional "Economia Social e Promoção de Emprego", pp. 9-32. Observatório do Emprego e Formação Profissional: Lisboa.

Ferreiro, M. F. P. (2010) 'Humanidade e Pluralidade: A Economia Social em Perspectiva'. Revista Dirigir, 109:3-7.

Ferreira, S. (2004) 'O Papel de Movimento Social das Organizações do Terceiro Sector em Portugal' paper presented at the 5th Portuguese Sociology conference. Sociedades Contemporâneas: Reflexividade e Acção, 12-15 May, University of the Minho, Braga.

Flick, U. (1998) An Introduction to Qualitative Research, London: Sage.

Franco, R. C., S. W. Sokolowski, E. M. H. Hairel and L. M. Salamon (2005) $O$

Sector não Lucrativo numa Perspectiva Comparada, Lisbon and Baltimore, MD:

Universidade Católica Portuguesa/ Johns Hopkins University.

Gaiger, L. I. and A. S. Corrêa (2011) 'O Diferencial do Empreendedorismo

Solidário', Ciências Sociais Unisinos, 47 (1):34-43.

Galera, G. (2004) 'The Evolution of the Co-operative Form: An International Perspective' In Borzaga, C. and R. Spear (eds.) (2004) Trends and Challenges for Co-operatives and Social Enterprises in Developed and Transition Countries. www.euricse.eu/sites/default/files/db_uploads/documents/1281454238_n630.pdf (consulted 15 November 2011).

Hespanha, P. (2000) 'Os caminhos e os descaminhos do terceiro sector a propósito da experiência portuguesa recente'. Actas do Seminário de Antropologia e Sociologia do Congresso Portugal-Brasil. Secção de Textos da Faculdade de Economia de Coimbra. Coimbra: Faculdade de Economia de Coimbra.

Laville, J.-L. (2009) 'A economia solidária: Um movimento internacional.' Revista Critica de Ciências Sociais, 84: 7-47. Coimbra: Centro de Estudos Sociais.

Laville, J.-L. and L. I. Gaiger (2009) 'Economia Solidária' In Gattani, A. S., Laville, J.-L., Gaiger, L. I. et.al (eds.) (2009) Dicionário Internacional da Outra Economia, pp. 162-168. Coimbra: Almedina.

Leadbeater, C. (1996) The Rise of the Social Entrepreneur. London: Demos. Mair, J. and I. Marti (2006) 'Social Entrepreneurship Research: A Source of Explanation, Prediction, and Delight', Journal of World Business, 41:36-44. Martin, R.L. and S. Osberg (2007) 'Social Entrepreneurship: The Case for Definition', Social Innovation Review, 5(2):27-39.

Morais, L. (2007) 'Economia social e solidária: do que se trata este complexo e contraditório setor? Balanço, tendências e perspectivas para análise do caso brasileiro.' Comunicação apresentada no Congresso Nacional da ABET, Salvador. http://www.tau.org.ar/html/upload/89f0c2b656ca02ff45ef61a4f2e5bf24/Artigo_ abet_07_1_.pdf. (Consulted 22 November 2011)

Nicholls, A. (2006) Social Entrepreneurship: New Models of Sustainable Social Change. Oxford: Oxford University Press.

Nicholls, A. and A. H. Cho (2006) 'Social Entrepreneurship: The Structuration of a Field' In Nicholls, A. (ed.) Social Entrepreneurship: New Models of Sustainable 
Social Change, pp. 99-118. Oxford: Oxford University Press.

Parente, Cristina (2011) Qualified Employment in the Third Sector in

Portugal. Voluntas: International Journal of Voluntary and Nonprofit

Organizations (2011): 1-20, June 02. DOI: 10.1007/s11266-011-9190-8.

Peredo, A. M. and M. Mclean (2006) 'Social Entrepreneurship: A Critical Review of the Concept', Journal of World Business, 41:56-65.

Perista, H. (2001) 'Social enterprises in Portugal - The case of CECI's Cooperatives for Rehabilitation of People with Disabilities, Lisboa, CESIS

- Centro de Estudos para a Intervenção Social' - paper presented at the Trento International Conference, The Social Enterprise. Polgreen, L. and V. Bajaj (2010) 'India Microcredit faces Collapse from Defaults' The New York Times 17

November, www.nytimes.com/2010/11/18/world/asia/18micro.html (consulted 17 November 2011).

Quintão, C. (2004) 'Terceiro Sector: Elementos para Referenciação Teórica e Conceptual' paper presented at the 5th Portuguese Sociology conference, Sociedades Contemporâneas: Reflexividade e Acção; Atelier: Mercados, Emprego e Trabalho.

Quintão, C. (2011) 'O Terceiro Sector e a Sua Renovação em Portugal. Uma abordagem preliminar'. IS Working Paper. 2(2). http://isociologia.pt/App_Files/ Documents/is-wp-ns 002 110411025242.pdf (consulted 10 June 2011).

Salamon, L., Sokolowski, S. W., Haddock, M. and H. S. Tice (2012) Portugal's Nonprofit Sector in Comparative Context. Johns Hopkins Center for Civil Society Studies and Portugal's Instituto Nacional de Estatística (INE). http://ccss.jhu. edu/wp-content/uploads/downloads/2012/04/Portugal_Comparative-Report FINAL 4.2012.pdf (consulted 12 May 2012).

Salamon, L. (1992) America's Non-profit Sector: A Primer. New York, NY: Foundation Center.

Santos, B. S. (1993) 'O Estado, as Relações Salariais e o Bem-estar Social na Semiperiferia: O Caso Português' In B. de S. Santos (ed.) Portugal: Um Retrato Singular. Oporto: Afrontamento.

Weerawardena, J. and G. Mort (2006) 'Investigating Social Entrepreneurship: A Multidimensional Model', Journal of World Business, 41:21-35.

Yunus, M. (2011) 'Sacrificing Microcredit for Megaprofits' The New York Times 14 January. www.nytimes.com/2011/01/15/opinion/15yunus.html (consulted 14 January 2011). 